\title{
パルス的マイクロ波放電による 低密度ガス流の直視法*
}

岡林典男, 遠山澗志, 石塚 浩**

(東大理 - 物理)

(1966 年4月27日受理)

\section{$\S 1$ はじめに}

核融合装置，ブラズマの研究において，中性ガスのパルス的注入がしばしば行われ，多量のプラ

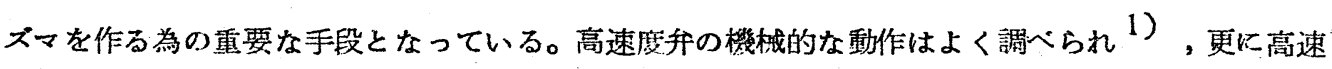
度の動作を目指す新しい設計や試験も種々行われている。2）しかしながら，高速度弁から流れ出る

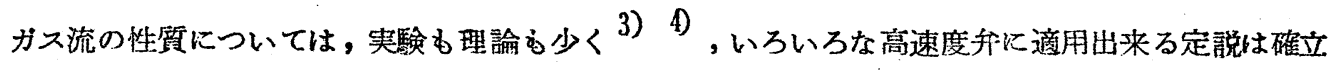
されていない。その理由の一つとして，非定常な低密度ガス流を測定する手段の乏しさがあげられ よう。

低密度ガス $\left(10^{-3} \sim 1 m m \mathrm{Hg}\right) の$ ふるないを調へる為に，一般には Uarshal1 ${ }^{5}$ のダー シ(開いた $6 \mathrm{AH} 6$ ) やその変形が用いられるが，それには幾つかの欠点がある。ダーシの在在が ガスの流れを乱すこと，ガス圧の分布を一時に全体にわたって見ることが出来ないこと等である。 Electron beam densitometer ${ }^{6)}$ むある場所におけるガス仕しか測れない。シュリーレン 法や干涉法などの光学的測定は，ガス正が $1 \mathrm{~mm} \mathrm{H} g$ 以下では難しい。

そこで我々は強いバルス的マイクロ波を低密度ガス流に当て〉放電を起させ，その発光状態によ

* Instantaneous Visualization of Rarefied Gas Flow by Means of Nicrowave Discharge

** Michio Okabayashi, Hiroshi Toyama and Hiroshi Ishizuka (Department of Physics, University of Tokyo, Tokyo) 
岡态槙山・石塚

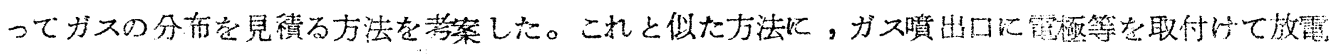

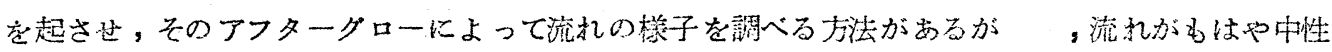

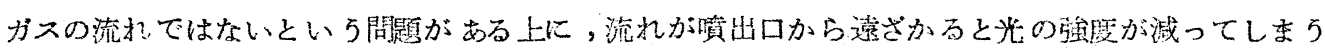

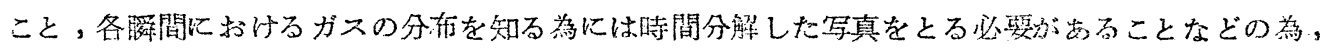

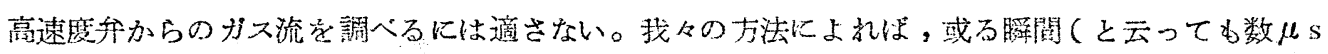

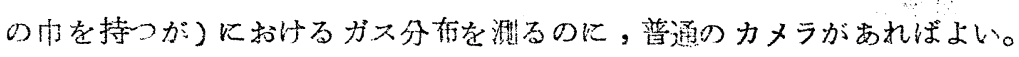

この方法を用いてガスの分布状熊をどこ迄定䀯的に知り得るかは今後の問題であるが，ガス流の

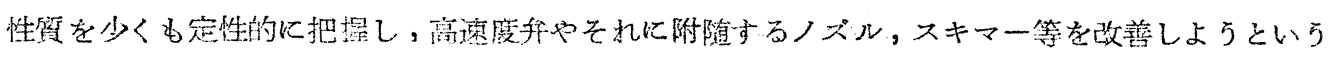

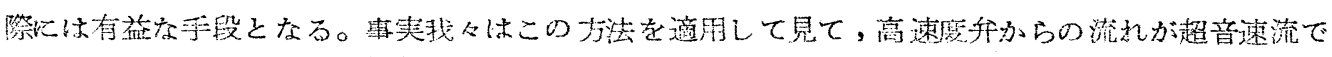

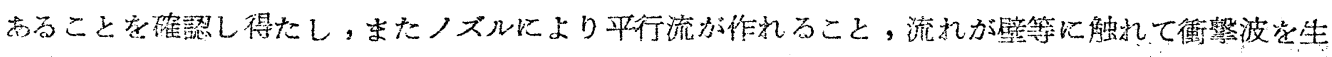
じる有榜などを知ることが出来た。パフからの流れの物理的解积，パフの改良等についての詳いい 研究は機会を改めて報告したい。

\section{$\$ 2$ 测定法の原理}

バフから流れ出したガスは摭がりを持っている。それへマイクロ波をあてるとある範田たけ放電 すると思われるのであるが，放電範囲（Ｌ）を中性ガス分布の関係，特に中性ガス分布の半值巾(a)

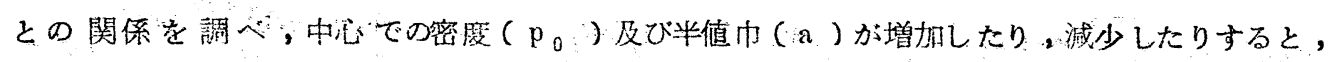
L/aがぞのように变るか明らかにしておく必琹がある。以下不均一ガスにおけるマイク口波放電 範囲について考祭してみよう。

\section{微分方程式}

$$
\frac{\partial}{\partial t} n-\frac{\partial}{\partial x}\left(D \frac{\partial}{\partial x} n\right)-\nu n=0
$$

$$
\begin{aligned}
& \mathrm{n}: \text { 麗子密度 } \\
& \mathrm{D}: \text { 霓子の抾故係数 } \\
& \nu \text { : ionization frequency }
\end{aligned}
$$

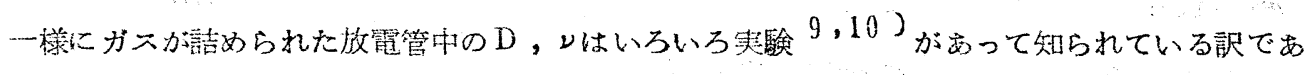
るが，不均一ガスの場合にむ，D，忧物理的烤克てその場所だけの函数であるので，均一ガス 


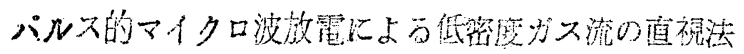

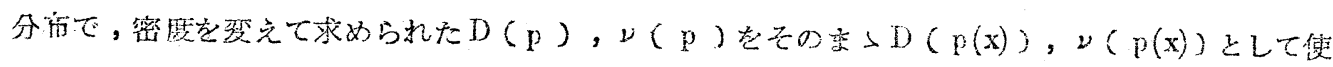
用する。

$$
\begin{aligned}
& \nu=\frac{\mathrm{eE}_{\mathrm{e}}^{2}}{\mathrm{u}_{\mathrm{i}} \mathrm{m}_{\mathrm{c}}} \\
& \nu_{\mathrm{c}}=2 \sim 5 \times 10^{9} \mathrm{p}^{9,10)} \\
& \mathrm{E}_{\mathrm{c}}^{2}=\frac{\mathrm{E}^{2}}{1+\left(\frac{\omega}{\nu_{\mathrm{c}}}\right)^{2}} \\
& \mathrm{~B}^{2}=\frac{\mathrm{E}_{\mathrm{p}}^{2}}{2}
\end{aligned}
$$

$\mathrm{E}_{\mathrm{p}}$ : マイクロ波のピーク電阷

p : 密度 (気压 $m m H g$ 単位)

$\mathrm{u}_{\mathrm{i}}$ ：電子1 1 を性分子上り放出させるのに必要なエネルギー

D p : $2.9 \sim 3.2 \times 10^{5}$

(数字の入っている式は，ming，cm単位で矅る。

我々の場合 $\omega \gg \nu_{\mathrm{c}}$ であるから

$$
\begin{aligned}
& \nu=\nu_{0} \mathrm{p}(\mathrm{x})=\nu_{0} \mathrm{p}_{0} \mathrm{f}(\mathrm{x}) \\
& \mathrm{D}=\frac{\mathrm{D}_{0}}{\mathrm{p}}=\frac{\mathrm{D}_{0}}{\mathrm{p}_{0}} \frac{\mathrm{l}}{\mathrm{f}(\mathrm{x})}
\end{aligned}
$$

我々のマイクロ波は $1 \mathrm{kV} / c m$ 電場であるので

$$
\begin{aligned}
& \nu_{0}=(2.4 \sim 0.8) \times 10^{9} \\
& D_{0}=3 \times 10^{5}
\end{aligned}
$$

式は

$$
\frac{\partial}{\partial t} n-\frac{D_{0}}{p_{0}} \frac{\partial}{\partial x}\left(\frac{1}{f} \frac{\partial}{\partial x} n\right)-\nu_{0} p_{0} f n=0
$$

となる。簡単には解けないのでモルデを考えてみる。 


\section{岡林 - 淩山・石塚}

\section{モ}

放電が起ったとして, 一定の距離（２Ｌ）の中では成長速㿑（て）で霓子数（n）が增加してい って，x ZLでは電子数は 0 とする。央際には電子数は急に $\mathrm{x}=\mathrm{L}$ で 0 にはならすに指数函数的に

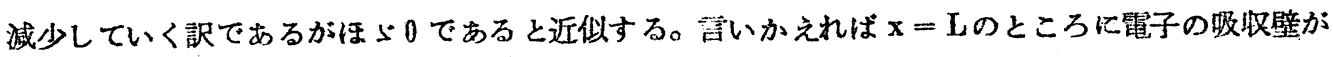
自然に出来るとする。始めからLが分っている訳ではないので（几）と（て）の関俰が求をること になる。

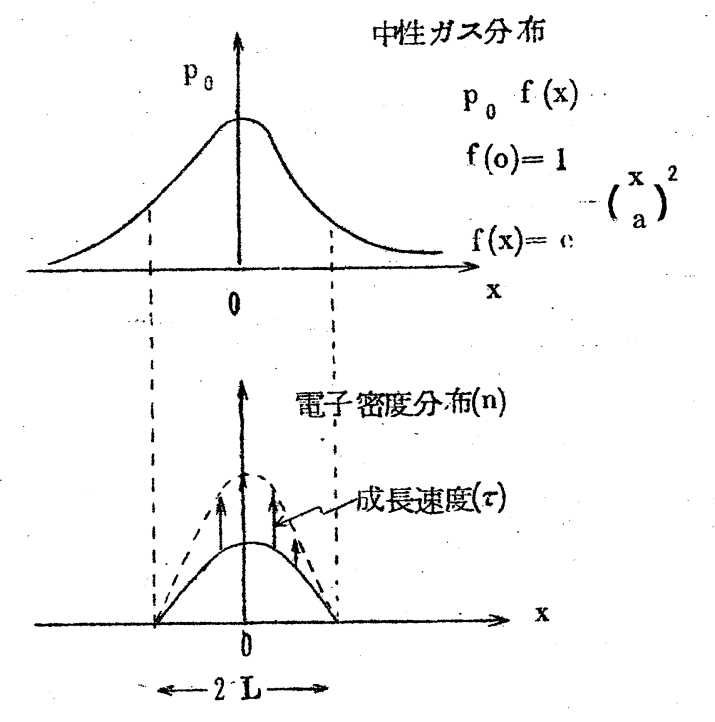

$\frac{\partial \mathrm{n}}{\partial \mathrm{t}}=\frac{\mathrm{n}}{\tau} \mathrm{z} \mathrm{L}$

$\frac{\mathrm{p}_{0}^{2} \nu_{0}}{\mathrm{D}_{0}} \mathrm{a}^{2} \equiv \mathrm{k}^{2} \mathrm{a}^{2}$ が我ふの場合

電場が大きいために，30〜70 と

言ら大な值になることから，

W K B 法を使って解くと

$$
\begin{aligned}
& n=c^{\frac{t}{\tau} \sqrt[4]{\frac{f}{f-b}}} \cos \left\{k a \int_{0}^{x / a}\right. \\
& \sqrt{f(f-b)} d z\} \\
& z=\frac{x}{a}
\end{aligned}
$$

$$
\begin{aligned}
& b \equiv \frac{1}{p_{0} \nu_{0} \tau} \\
& f(z)=e^{-z^{2}} \\
& x=L \text { で } n=0 よ り \\
& k \text { a } \int_{0}^{L / a} \sqrt{f(f-b)} d z=\frac{\pi}{2}
\end{aligned}
$$

むし，fが一様で $\mathrm{f}=1$ とするとこの式は 


$$
\sqrt{\frac{\nu}{D}} L \sqrt{1-\frac{1}{\tau \nu}}=\frac{\pi}{2}
$$

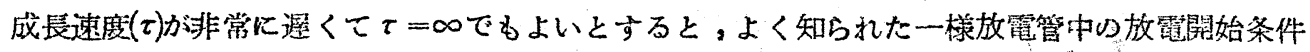

$$
\frac{\mathrm{D}}{\Lambda^{2}}=\nu \quad \Lambda=\frac{\ell}{\pi} \quad \ell: \text { 放電管㨁径 }
$$

が出る。それには我々の場合き=2 Lと置けばよく，確かに 2 Lは直径を㳖わしている。たからこ

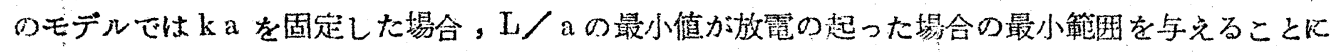
なる。上/aの大きい方の限界はモデルの不自然さをなくなると变化すると思われるので，重要で はないであろう。(いろいろなてについては第1図を参照)

$$
\text { モ }
$$

モデル1より少々精密にして $\mathrm{x} \rightarrow \pm \infty て ゙ \mathrm{n} \rightarrow 0$ で，|x $1 \leq \mathrm{L}$ では成與速度（て）でおるが， $|\mathrm{x}| \geq \mathrm{L}$ では $\tau=\infty$ として，同じくW K B. 法で求めると解は

$$
\begin{aligned}
& |x|<a \sqrt{-\log b} \quad n=A e^{\frac{t}{\tau}} \sqrt[4]{\frac{f}{f-b}} \cos \left\{k a \int_{0}^{x / a} \sqrt{f(f-b)} d z\right\} \\
& a \sqrt{ }-\log b<|x|<L \quad n=B e^{\frac{t}{\tau}} \sqrt[4]{\frac{f}{b-f}} \exp \left\{-k a \sqrt{\frac{x}{a} \sqrt{f(b-f)} d z}\right\} \\
& L<|x| \quad n=C \sin \left\{k a \int_{\infty}^{x / a b} f d z\right\}
\end{aligned}
$$

関保式は

$$
\mathrm{ka} \int_{0}^{\sqrt{-\log b}} \sqrt{f(f-b)} \mathrm{d} z=\frac{\pi}{4}
$$$$
b\left(\frac{L}{a}\right) \frac{1}{f\left(\frac{L}{a}\right)}+2 k a\left\{b-f\left(\frac{L}{a}\right)\right\} \sqrt{\frac{b}{f\left(\frac{L}{a}\right)}}-1=\frac{2 k a\left\{b-f\left(\frac{L}{a}\right)\right\}}{\tan \left\{k a \int_{y / a}^{\infty} f d z\right\}}
$$ 


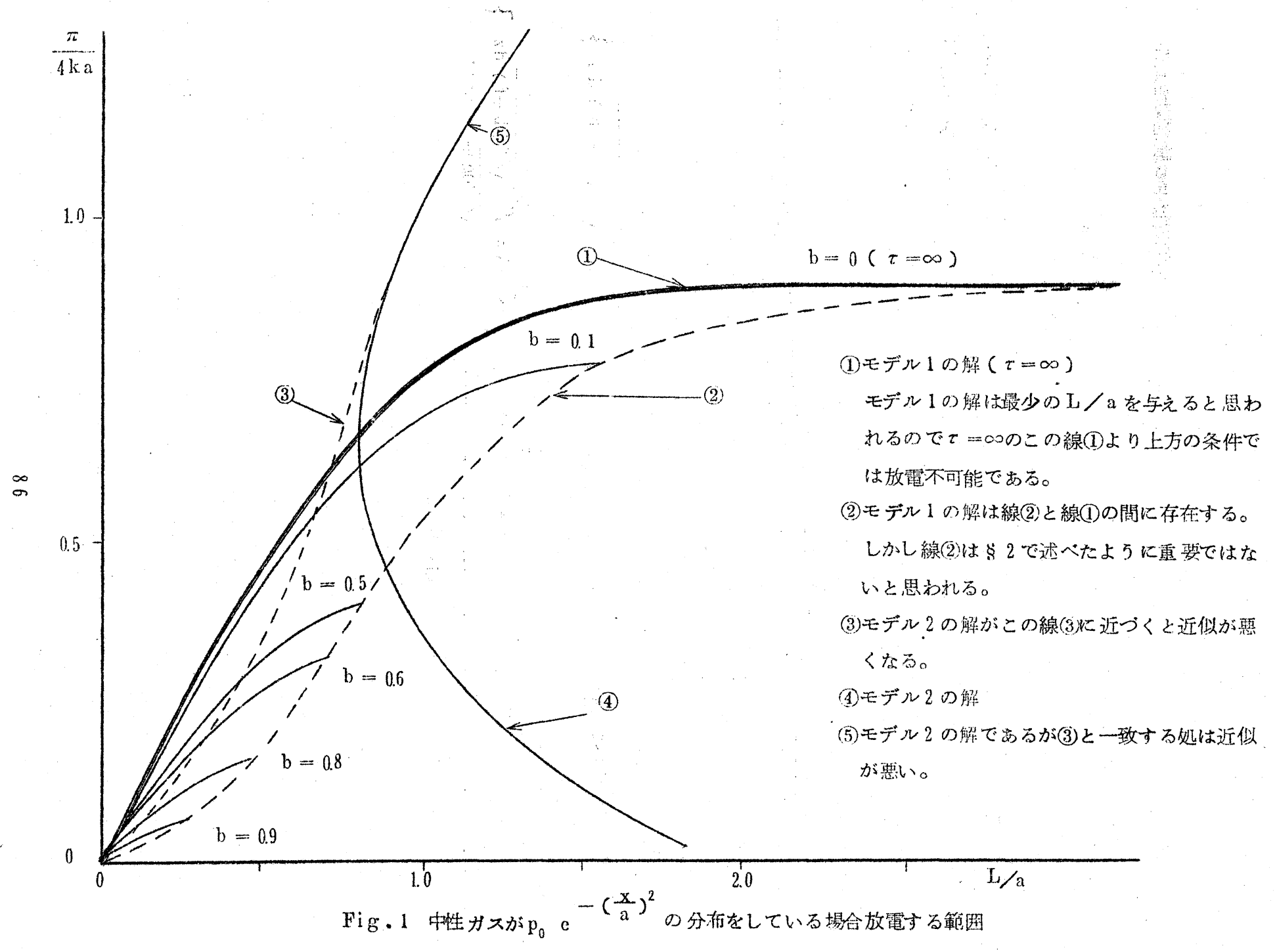


これはW、K、B法の接續からと，|x|=LでLosarithnic derivativeが连続と䓂う条

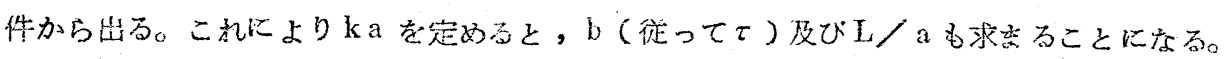
k a が大きいとさには

$$
b=1-\frac{1}{k_{a}}
$$

モデル3

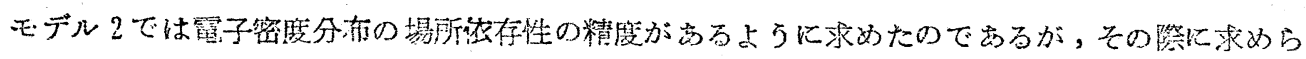
れた時間依存のバラメータbを，それ以外のオ法で求的たものと比較し，モデル2 及びその近似法 の良否を考它てみたいと思う。

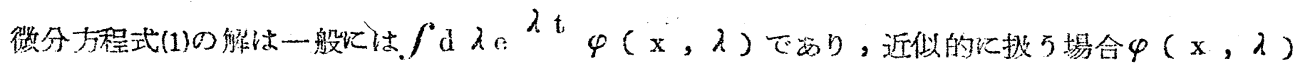

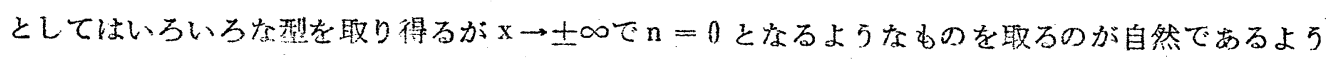
火思われる。例党ば $\varphi(x, \lambda)=\mathrm{e}^{-\frac{1}{2 \beta(\mathrm{x})} \mathrm{x}}$ を取り，境界条件を考慮儿入れると，連続的病

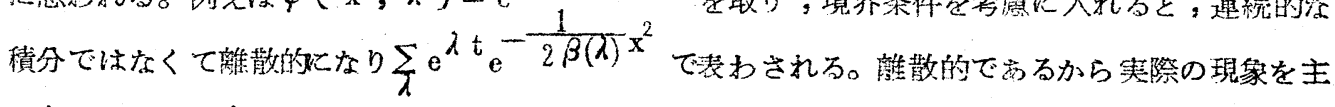

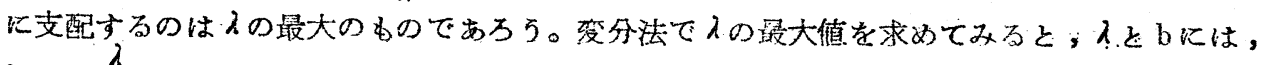
$\mathrm{b} \equiv \frac{\lambda}{\mathrm{p}_{0} \nu_{0}}$ の関係があるので, $\mathrm{b}$ が求をり

$$
\begin{aligned}
& \mathrm{b}=\frac{\lambda}{\mathrm{p}_{0} \nu_{0}}=-\frac{4\left(\beta^{2}+\beta-\frac{1}{2}\right)}{(2-5 \beta)(1+\beta) \sqrt{1+\beta}} \\
& \mathrm{k}^{2} \mathrm{a}^{2}=\frac{(2-5 \beta)(1+\beta)^{\frac{3}{2}}}{2 \beta^{2}(1-\beta)^{5 / 2}}
\end{aligned}
$$

$\mathrm{b}$ とa の関倸は, $\mathrm{ka}$ が小さい方ではモデル 2 の結果と factor 2 程ずれるが，kaが大きい ときは

$$
\mathrm{b}=1-\frac{1}{\mathrm{ka}}
$$


岡菻・渌打・石愻

でモデル2と一致する。

よってモデル2の解は時間的にも满足のいくむのであるよ5に䍐われる。このモデルでは電子尔 布の半值巾が求まるが，敃電範囲についてはわからない。

二次元でも式及び結舀は同じなので中性ガスが円柱状に存在してそれが桩散していく場合にマイク 口波で放雎させたとするとし/、がぞのように变っていくか，大体の様子を知ることが出来る。そ 礼には， $\mathrm{p}_{0} ， \mathrm{a}$ こ多㹡散により時間的媇化していくが，ガスの全量は一定であるとすると， $p_{0}(t), a(t) \infty{ }^{\prime}$ 間

$$
\begin{aligned}
& \int_{0}^{\infty} \mathrm{p}_{0} \text { f } 2 \pi \mathrm{rdr}=\mathrm{const} \text { より } \\
& \mathrm{p}_{0}(\mathrm{t}) \mathrm{a}^{2}(\mathrm{t})=\mathrm{const} \text { と言う関係がある。 }
\end{aligned}
$$

$\mathrm{ka}$ と㕩万量は $\mathrm{k}=\mathrm{p} \quad \sqrt{\frac{\nu_{0}}{\mathrm{D}_{0}}}$ のため

$$
\frac{1}{\mathrm{ka}} \propto \mathrm{a}(\mathrm{t})
$$

半径が 2 倍になれば $\begin{gathered}1 \\ \mathrm{ka}\end{gathered}$ す2 倍になることになって, $\frac{1}{\mathrm{ka}}=0.05$ が最初とすると，モデル2 によると $\mathrm{L} / \mathrm{a}=1.65$ で半径が 4 倍になる索で観測したとするとし/ $\mathrm{a}=1.20$ で約 $25 \%$

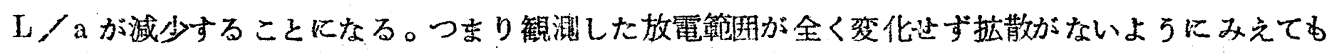
3 $0 \%$ 程中性ガスの半值巾が増していることになる。

上述のモデルでは成長速度が場所により变らないこと，電場の絶対值が場所こより，又時關的に变 化しないと仮定してい。電子密度成長が遅い場合及び初期においては成立するが電子密度が増加 して電場が湾化するようになると（後述）最早正磪ではなく，電子密度分布は变ってくる。しかし

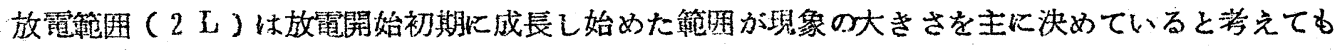
よいと思心れる。つまり電子分布について最早正確でなくとも初期の放電成長範国（２Ｌ）は放䉓 の起る籍湖をだいたい与えていると思われる。 
パルス的マイクロ波放電による低密管ガス流の直視法

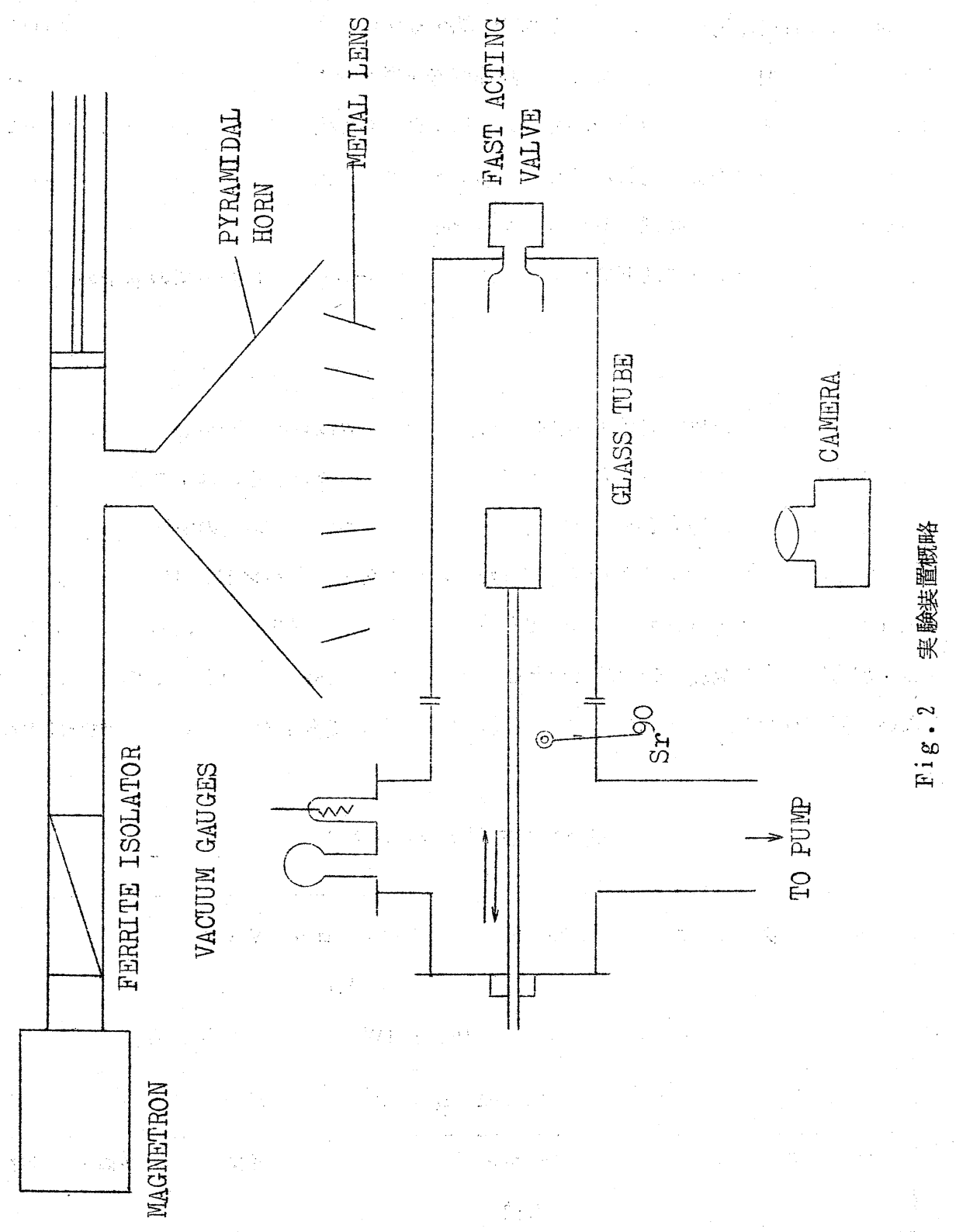




\section{$\S 3$ 浡 瓂}

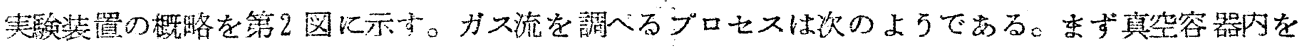
$1 \times 10^{-5} m \mathrm{H} g$ 以下にひいて抢く。高速度弁を㗢かせた後, 或る時間㩧らせてマグネトロンを 㗢ふせると，、イクロ波がホンを経て放射され，真空容器内にはその時刻のガス圧分斩に応じて放 笔がつく。その形は肉眼でもるかるし，写真にとることも出来る。マイクロ波をかける洔刻老䐓次 变えて以上の钼洌を繰返せば，流れの状態の眭間的变化がわかるわけである。

装䁂の主要なパラメータは下装の如くである。パラメータの䀧択に当っての若干の注意を下に述へ る。

(i) マイクロ波

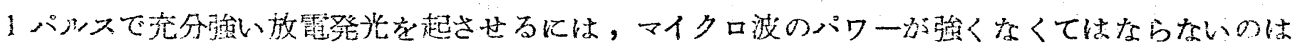

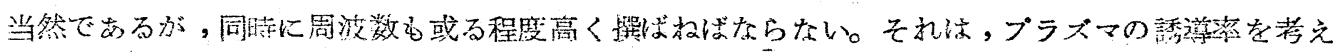
ればわかるように, 波長入(cm)の波は $10^{13} / \lambda^{2}$ ( cm-3 - 以上の電子密度をるつプラズマに 入れず，说ってその密度を超す放電を起せないからである。 S バンド2 MWを用いると，放電は一

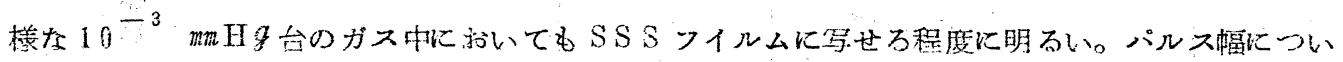

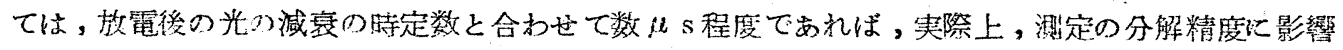
しない。佮にガスが $1000 \mathrm{~m} / \mathrm{s}$ の速さで勒いていたとしても，沈りながら動く距離は数 $m m$ である。

装置の主要なパラメタ

\begin{tabular}{|c|c|c|c|c|}
\hline$\checkmark$ & 19 & ㅁ & 波 & 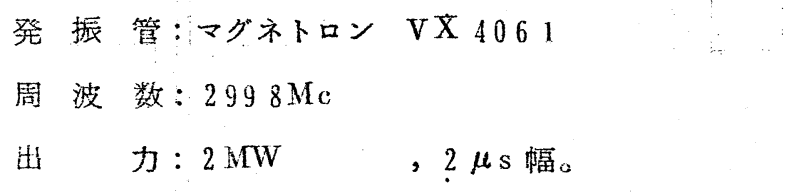 \\
\hline 高 & 速 & 度 & 弁 & Lowder and Hoh 11 ) の型 \\
\hline 真 & 空 & 容 & 器 & $\begin{array}{l}\text { コーニング・ダブルタフ・パイプ。 } 6 \text { " } \text { 直管，十字管 } \\
\text { 等可換。 }\end{array}$ \\
\hline 放 & 射 & 線 & 源 & $\mathrm{Sr}^{90} \quad 10 \mathrm{~m} \mathrm{Ci}$ \\
\hline 辈 & 影 & 万 & 法 & 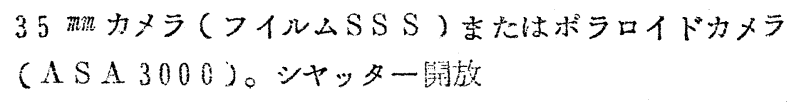 \\
\hline
\end{tabular}




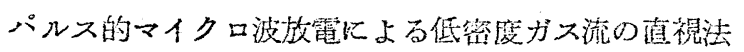

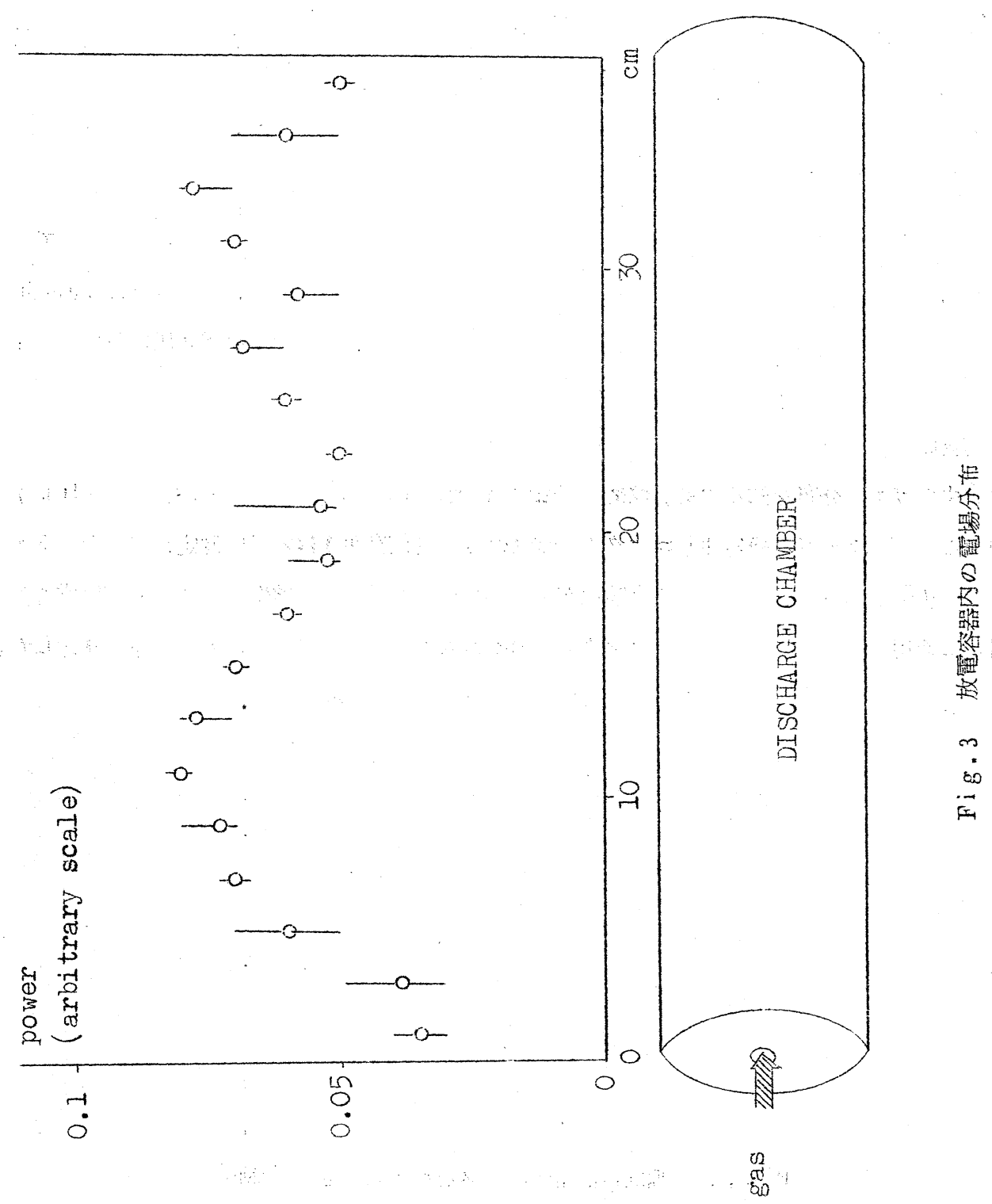


観測すべ空間に执いて，マイクロ波電場の强さは一様であることが望むしい。ホーン（開口が $20 \mathrm{~cm} \times 40 \mathrm{cmos}$ と゚ラミッド型)を用いてマイクロ波を拡げ，必要に応じて金属レンズを便用して 電場の一様化を図った。マイクロ波電場強度の分布を測った結果は第 3 図の如くであり，真空容器 全体にガスをつめて放電させた写真は第 4 図の如くである。

マグネトロンは負荷インピーダンスによって発振が変化するので，フェライト・アイソレータを

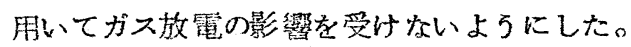

(ii) 放射線源

短いマイクロ波パルスで再現性よく放電を起さ好るには，可成り強い放身線によって種を作る必 琵がある。例えばMacKonald et al 9) に上れば，CWのマイクロ波放雪には5 4 Ciでよ いがパルス的マイクロ波放電には $5 \mathrm{mCi} の \mathrm{Co}^{60}$ (ガンマ線源)を必要とした。我ぬは $10 \mathrm{mCi}$ の $\mathrm{S} \mathrm{r}^{9.0}$ (ベータ線源) を真空容器に入れて, $10^{-2} \sim 10^{-3} m \mathrm{Hg}$ 台のガス区においても, 可成り再現性よく放電が起るようにした。

(iii) 真空度貺定

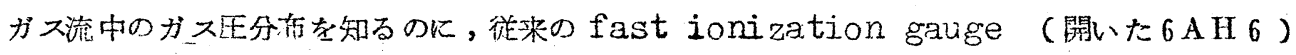

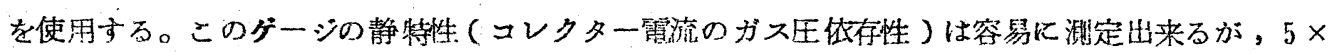
$10^{-3} m \mathrm{H} g$ 以上のガスEにおいて值線性がない。そしてそこでは静特性をそのま入非定常な流

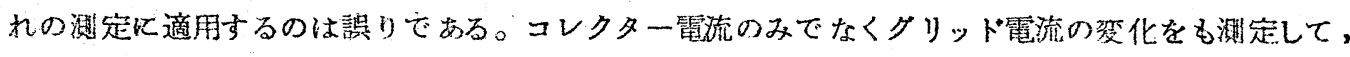
静特性から動特性を導く手続きを踏んで，流れの場合の損定に用いる。

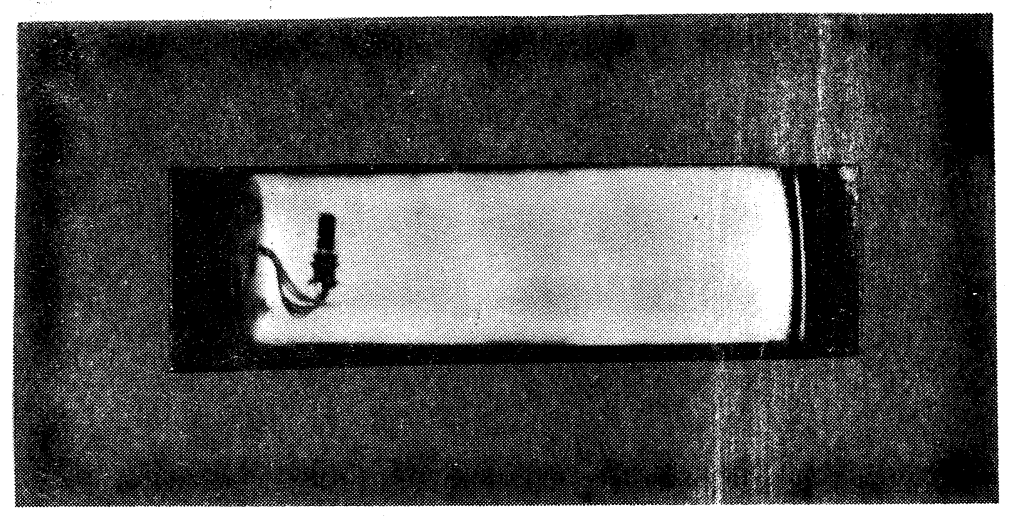

Fig.4 放電容器全体にガスをつかた場合の光強度

$$
\text { の一㥞性 (アルゴン } 0.06 \text { min } \mathrm{Hg} \text { ) }
$$




\section{パルス的マイクロ渃数電による低峰度ガス流の直視法}

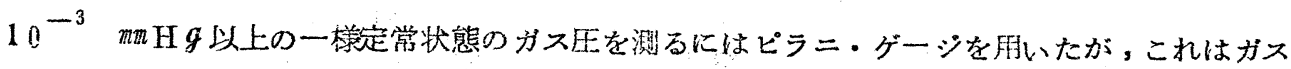

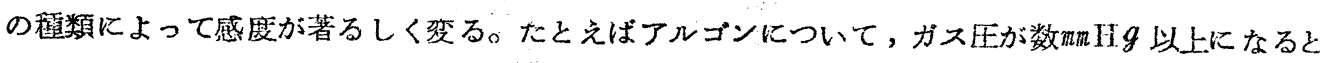
感度はほとんど無くなる。その為にピラニ・ゲージを，標準較を用マクレオート゚・ゲージにより較 正した。

\section{(iv) 高速度弁 (第 5 図)}

手軽に製作出来, コンデンサ・バンクむ比較的小容量ですむ Lowder and Hoh の型を用い た。コイルは 7 ターン, コンデンサ容量は $6 \mu \mathrm{F}$, 充麗々王は $5 \sim 7 \mathrm{kV}$, 升の背王は $1 \sim 5$ 気压 とした。ガス噴出口には diverging nozzle を取りつけられるようにし，なた下流に括入す るスキマーをも稗備した。

\section{$\S 4$ 貺定法に関する実験}

§2 で述べた測定原理を実験的に致べるたに，パフーノズルースキマーの系を用いてガス流を 作り,fast ionization gaugeにより求めたガス圧分布と我々の方法による登光状態とを比 較した。Fast ionization gauge (6AH6) を,スキマーから管軸に沿って約 $10 \mathrm{~cm}$ 離れた 位置で径方古に勳かして得たガス圧分布は第 6 図a の如くである。この図から，ガス压分布の半值 巾はガス注入量によらず約 5 cmである。これ认対しマイクロ波放電の光は，蟿方向の同一位置にお

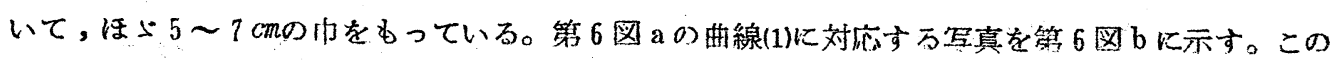
潰定からミ2に記したモデル2は，L/aに関して大体よいと思われる。

しかし発光の強さは，\$2 亿括いて計算した電子密度ほど強いガス压依存性を示さない。むしろ， 光る部分はほよ゙同じ明るさに写真に撮れる。こつで考えられるのが電子染度や光量の飽和である。 このことを確めるために，ガラス管内に一様にガスを充して，マイクロ波放電により生じる麗子密 度や光量を測定した。

ダブル・プローブをガラス管の径方向に動かした時の出力の例が第 7 図である。電子密度はマイ

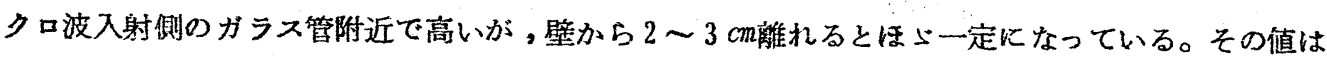
誤差の範围で $\mathrm{n} \simeq 10^{11} \mathrm{~cm}^{-3}$ ，即ち $\omega_{\mathrm{p}} \simeq \omega$ を成立させる密度と云える。寽電子密度は，放電開 始直後に約 $30 \mathrm{eV}$, マイクロ波が切れる時刻に $5 \mathrm{cV}$ 程度でむる。

放電と同時にブラズマ内のマイクロ波電場は極めて低くなることも锥測された。

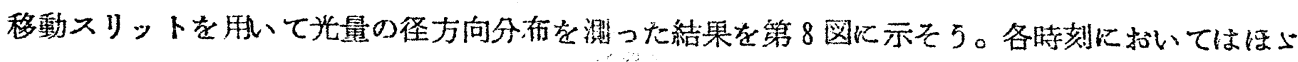

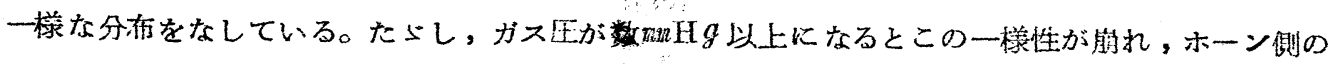




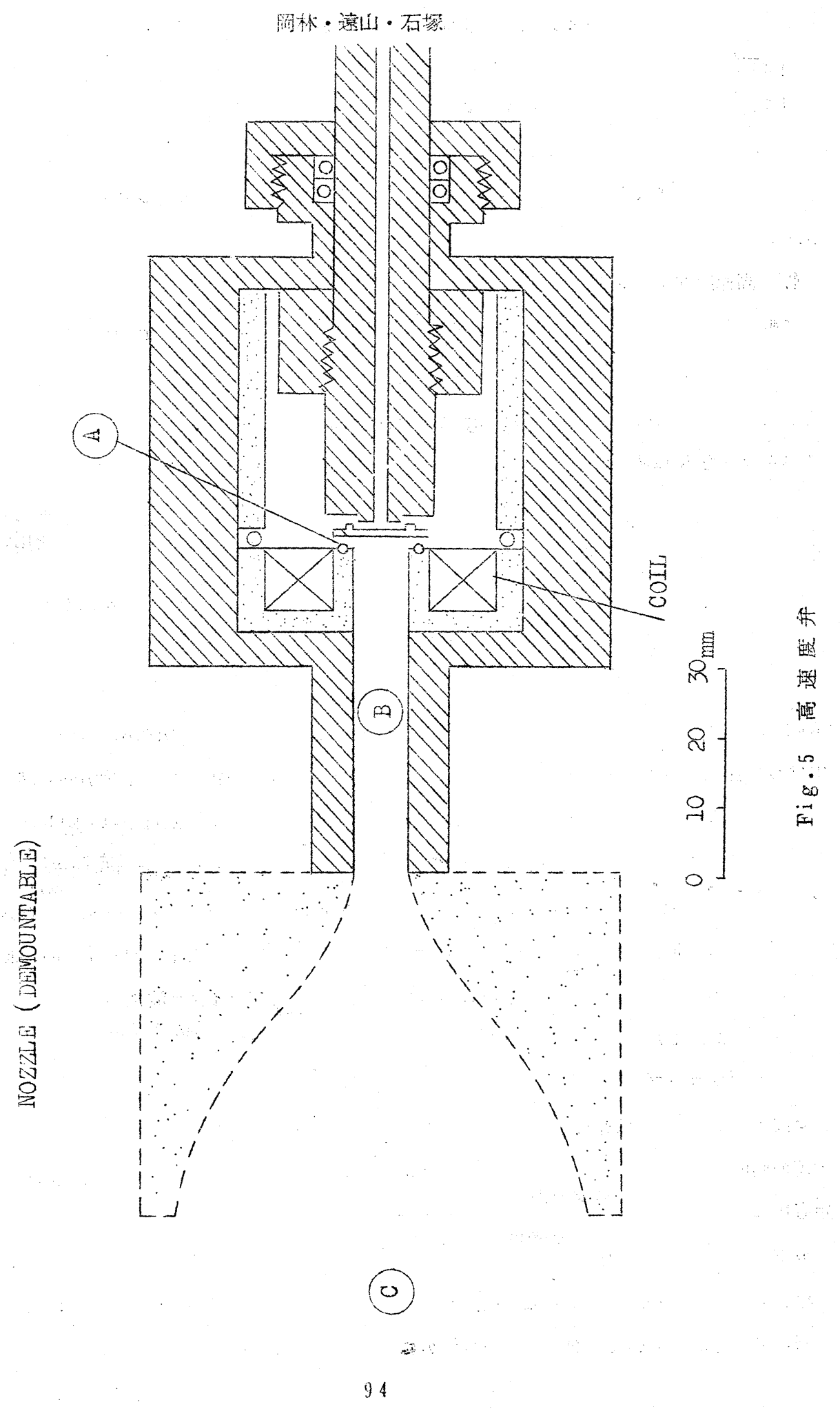




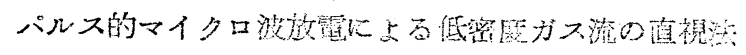
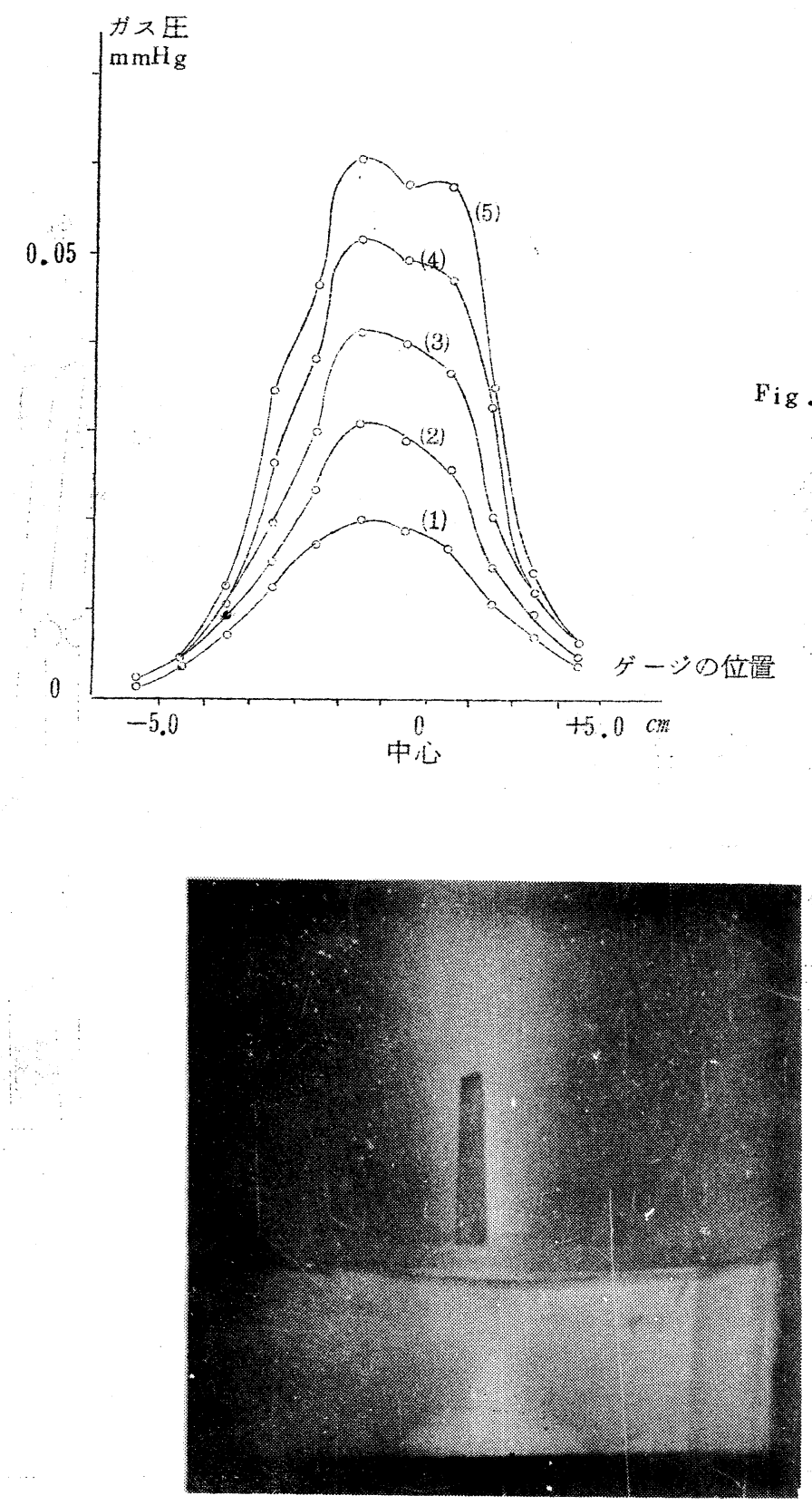

(b)

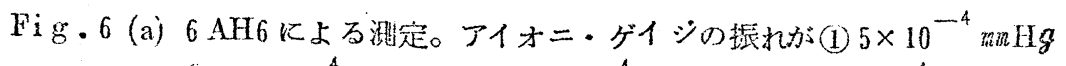
(2) $6 \times 10^{-4} \pi m \mathrm{Hg}$
(3) $7 \times 10^{-4} \mathrm{mHg}$
(4) $8 \times 10^{-4}$ m $\mathrm{mH}$
(5) $9 \times 10^{-4} \mathrm{~mm} \mathrm{Hg}$ の 檍

(b) (1) 之対志した放震写其 
岡林・迼山・石塚
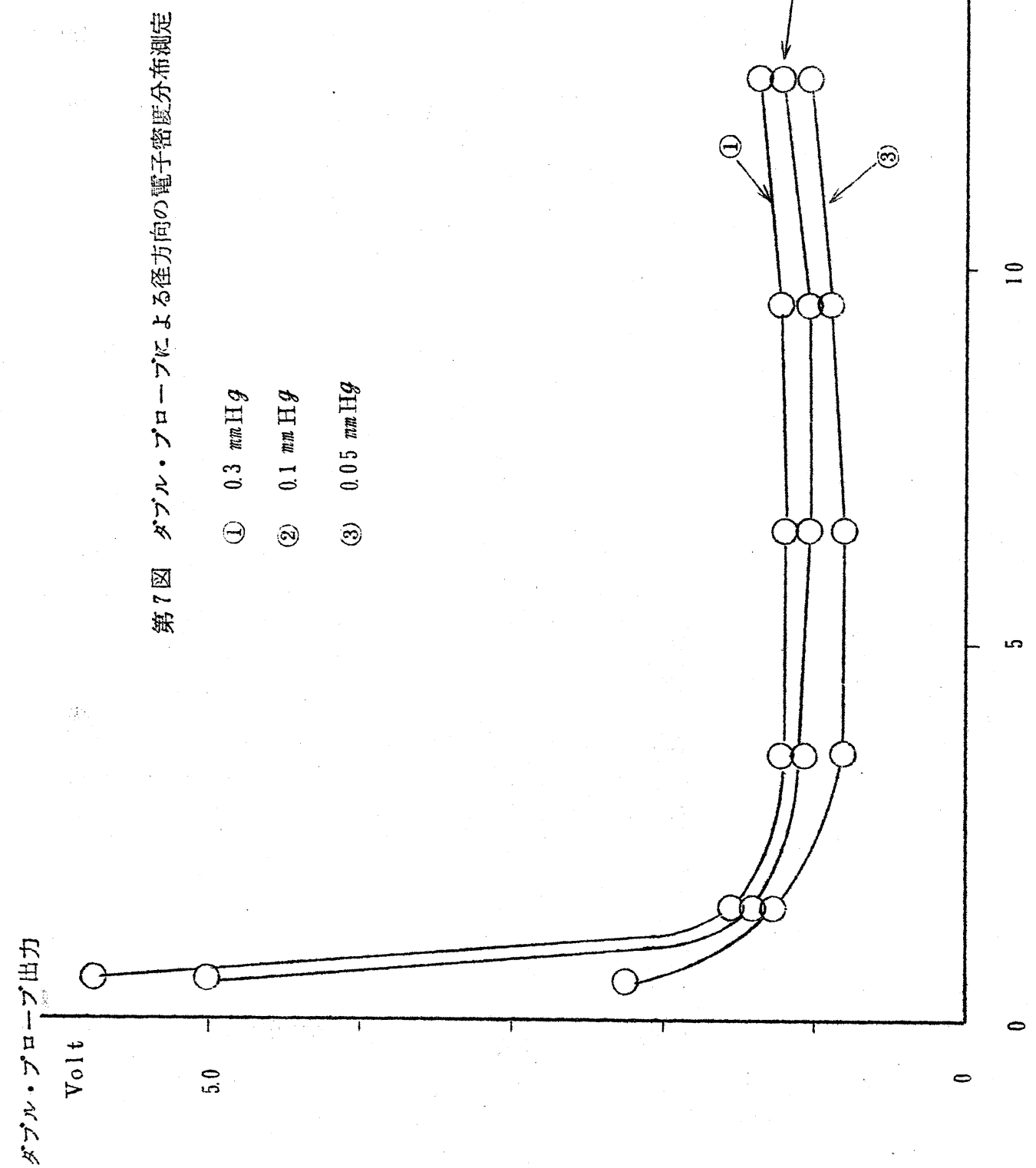


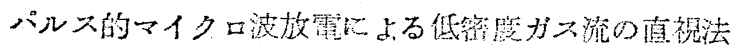

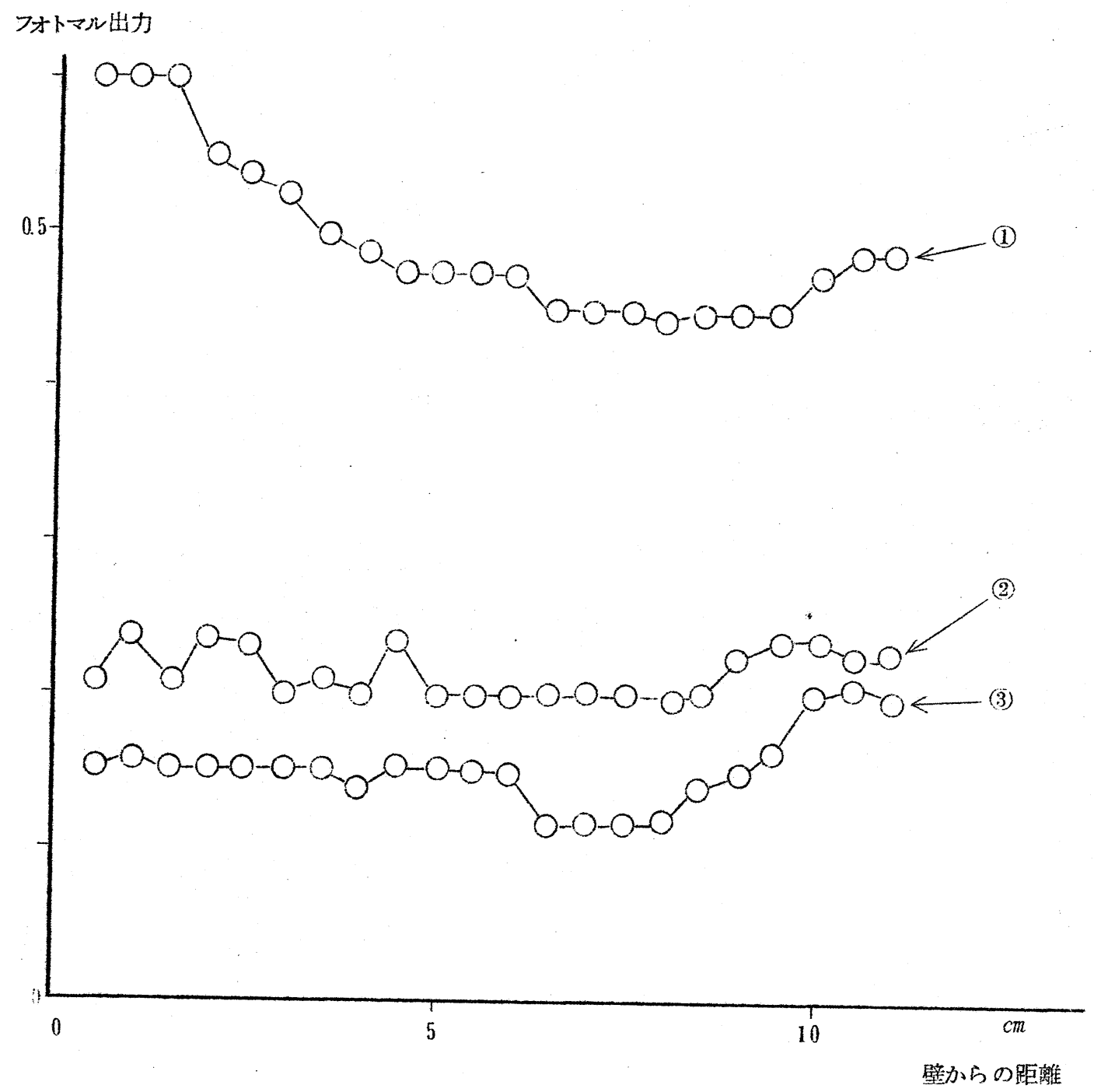

Fig.8フオト・マルによる径方向の光強层測定

( $0.1 m \mathrm{mg}$ )

(i) マイクロ波パルス開始後 0.5 $\mu$ sec

(2) $1.2 \%$

(3) $3,2 \%$ 


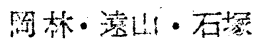
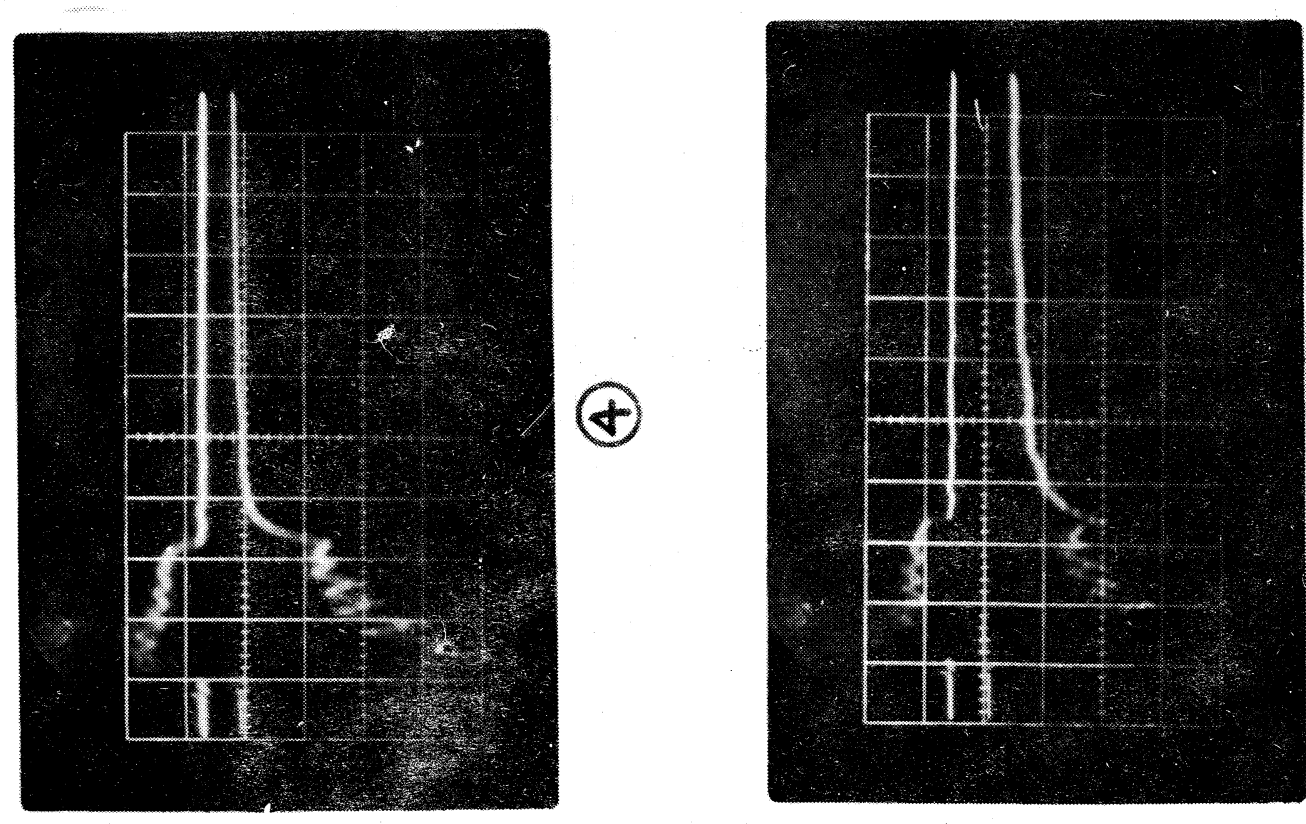

(1)
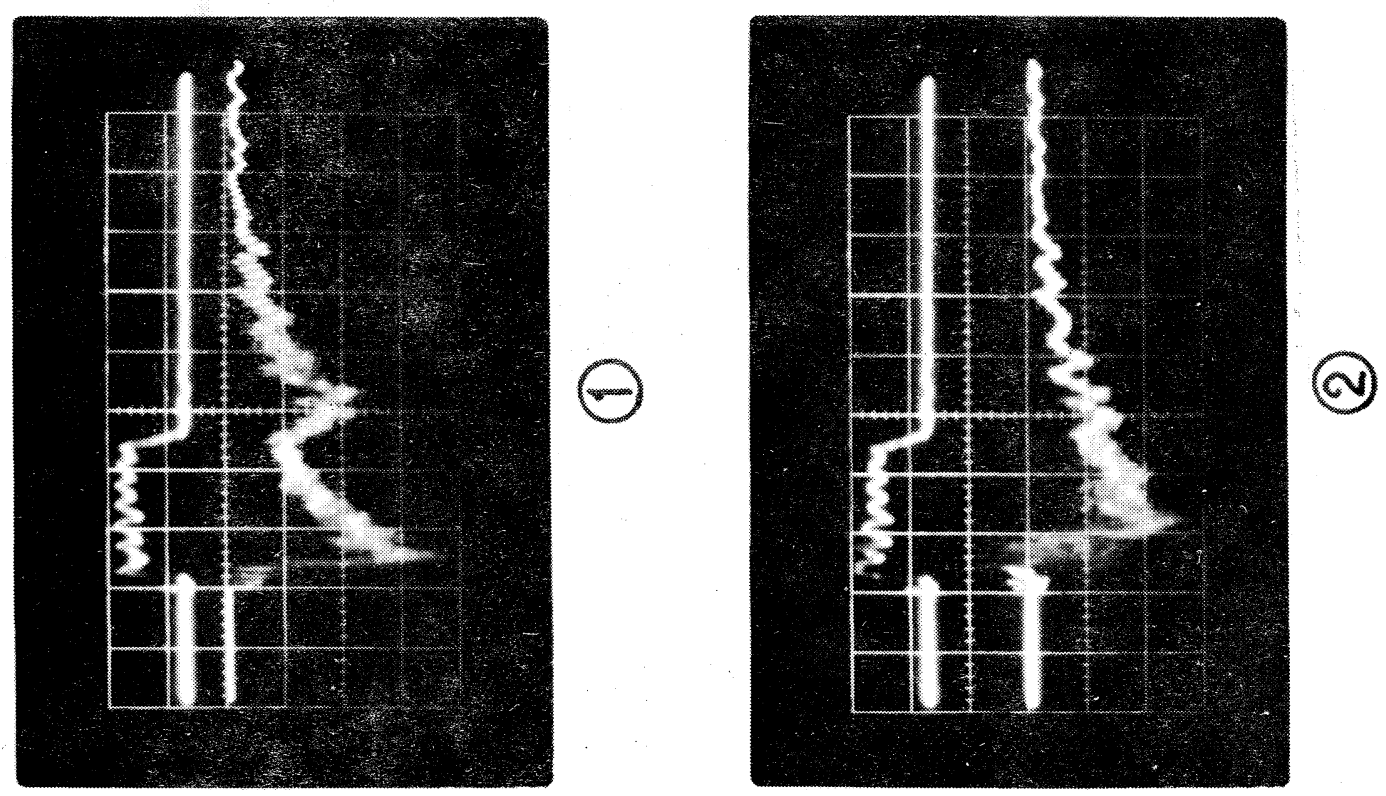


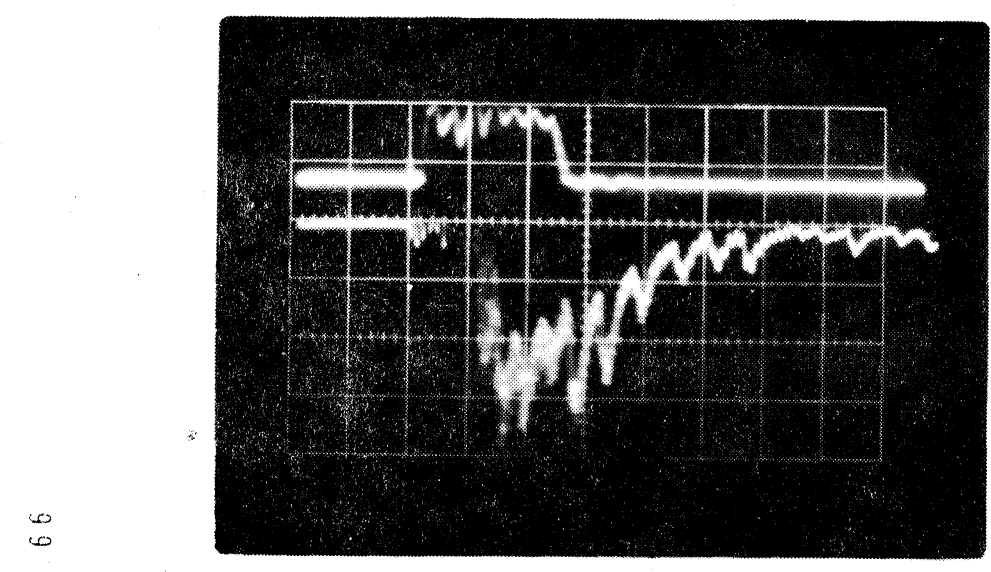

(3)

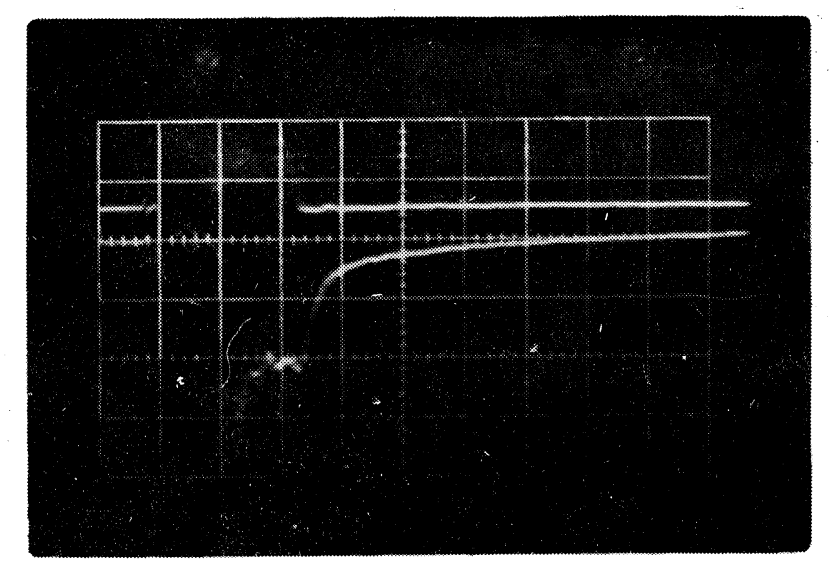

(6)

\begin{tabular}{|c|c|c|}
\hline $\mathrm{Fig} \cdot 9$ & (1) & ダブル・プローブ 測定 \\
\hline & (2) & $\prime \prime$ \\
\hline & (3) & $" \prime$ \\
\hline & (4) & フォトマルによる光強型 \\
\hline & (5) & $\prime \prime$ \\
\hline & (6) & " \\
\hline
\end{tabular}

$\begin{array}{lccc}0.3 & m \mathrm{H} g & 1 \mu \mathrm{sec} / \mathrm{div} & 1 \mathrm{~V} / \mathrm{cm} \\ 0.1 & m m \mathrm{Hg} & \prime & 1 \mathrm{~V} / \mathrm{cm} \\ 0.05 m \mathrm{HH} & \| & 1 \mathrm{~V} / \mathrm{cm} \\ 0.3 m n \mathrm{H} g & 1 \mu \mathrm{sec} / \mathrm{div} & 0.5 \mathrm{~V} / \mathrm{cm} \\ 0.1 m n \mathrm{Hg} & " & 1 \mathrm{~V} / \mathrm{cm} \\ 0.05 m \mathrm{Hg} & \| & 0.5 \mathrm{~V} / \mathrm{cm}\end{array}$




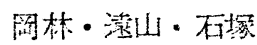

壁近くのみが光るようになる。

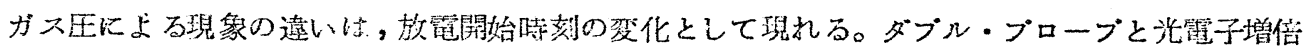

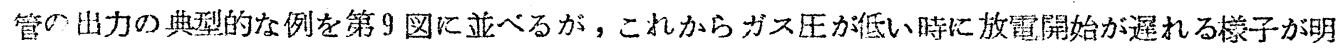
瞙であろう。

このような睍定から貺定法について次の上5に云えよ5。ミ2で与光た記述は，電子密度の增加

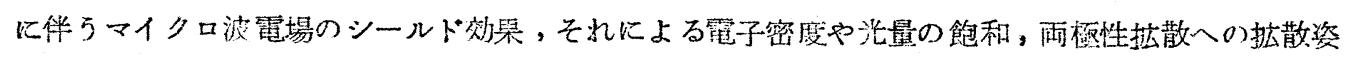

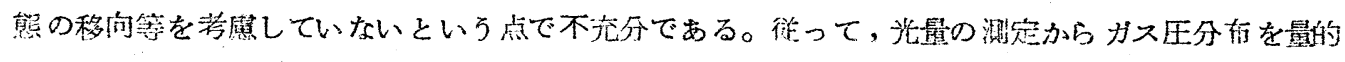

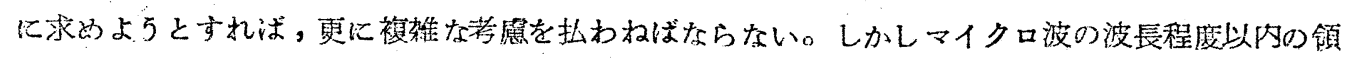

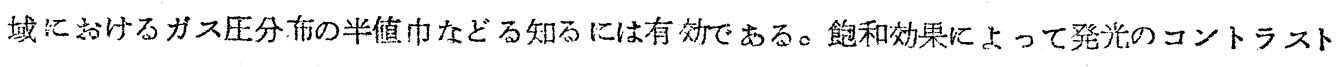
は下るが，ガス区の高い場所は低、坦航上りも明るい。例えばガラス管内に一様に薄くガスを充し て拈きそこにパフからガス流を注入してみると、確かに shock Iine が現れるのである(第 10 図)。

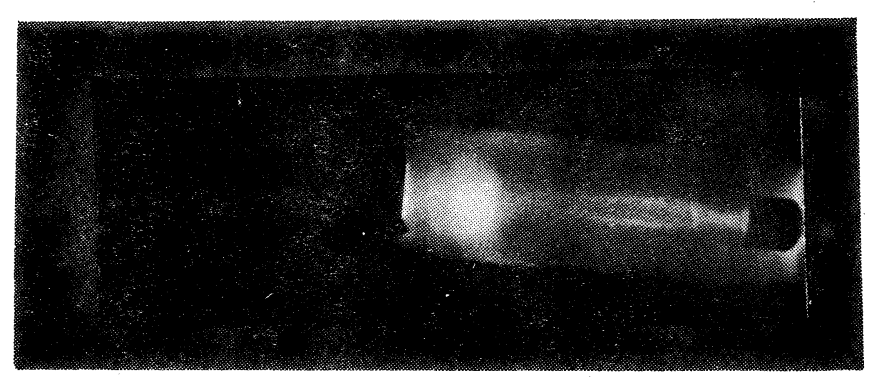

$$
\begin{aligned}
& \mathrm{Fig} \cdot 10 \text { 一模ガス( } 3.5 \times 10^{-2} \mathrm{~mm} \mathrm{H} \text { アルゴン) } \\
& \text { にパフでカス（空氮)を注入して } \\
& 700 \mu \mathrm{sad} \text { 後 }
\end{aligned}
$$


パルス的マイクロ波放電による低密度ガス流の直視法

\section{§5 パフからのガスの流れへの応用}

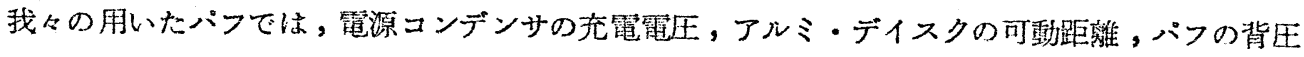
を変えることによって䇝入するグス量を制御出来る。その量は大巾に变えられるがマイクロ波放電 が起り得るのは，約 $10 \mathrm{mH} \mathrm{g} \mathrm{ce}$ 以上のプスを注入した時で沛る。同一量のガスを注入した場合 も，上記のバフのパラメータの組合せ力によって流れの様子が異ることが女ず判明した。與味ある

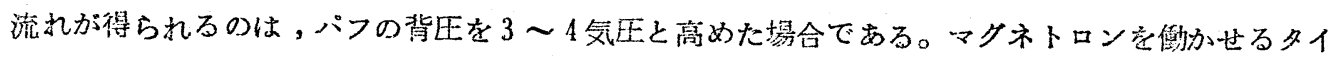
ミングを脽次变えて撮つた一連の写真を第 11 図に示す。第 5 図のノズルは取付けてない。この写 真からをた，流れの速度が500〜550m/s と超音速であることが知られる。このことはパフの前

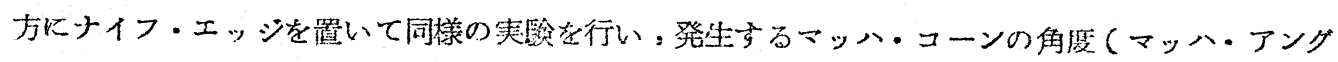

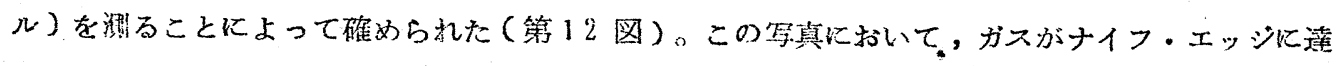

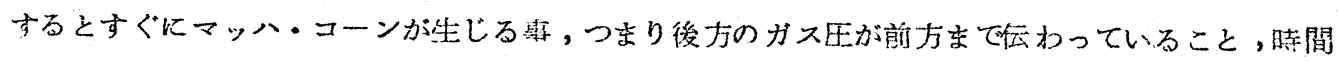
的にマッハ・アングルが変化しないこと虬，興味のあることである。

これらの事㫪讼次のように考兄られる。我々の運転条件ではアルミ・デイスクの開く間隔は 0.5

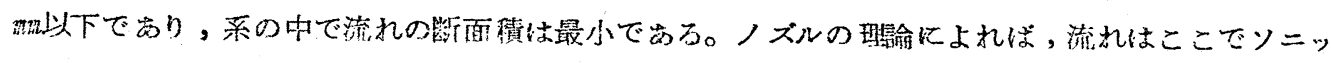

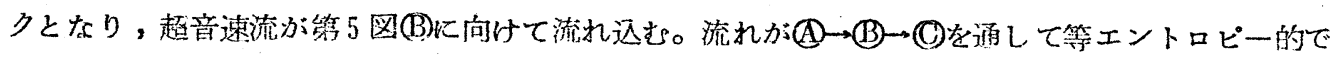
あれば(C)流れ出す流れのマッ八数は非常に大きくなる筈である。しかし実際には(ゆから(1)に流れ 込む際に流線の乱れが生じるのでマッ八数はをれ程あがらず，又(B)の中によどみの領域む生じるで 就

パフの出口で, 流れは可成り発散している。これを平行に噴出させるには，出口に第5图に示す ようなノズルを取り村け，流れのマッ八数を高めてやればよい。その例を第 13 图に示す。ナイフ ・エッシによるマッ八数は約 3 ，流机の速崚は理諭的に最高颠 $3 \times$ 音速に近い。このよ5にノ ズルによって流れを平行にすることが出来た。

第11図に抽いてなり時間が経っても後続は切れていない。これは上述したように，超音迹流 以外よどみの領域のガスが後になって浸み出して来るたいでなかろうか。後続を切る方法として 上記の平行流にローテイテング・デイスクの技術を用いることも考えられるが ${ }^{12}$ ), 我々は第14 図の上うな，上どみの生じ得る領域を小さくした，改良型の高速尉升を武作した。その結果，予想 通りに後続部分を非常に減らすことが出来た(第15 図)。 


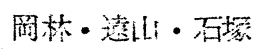

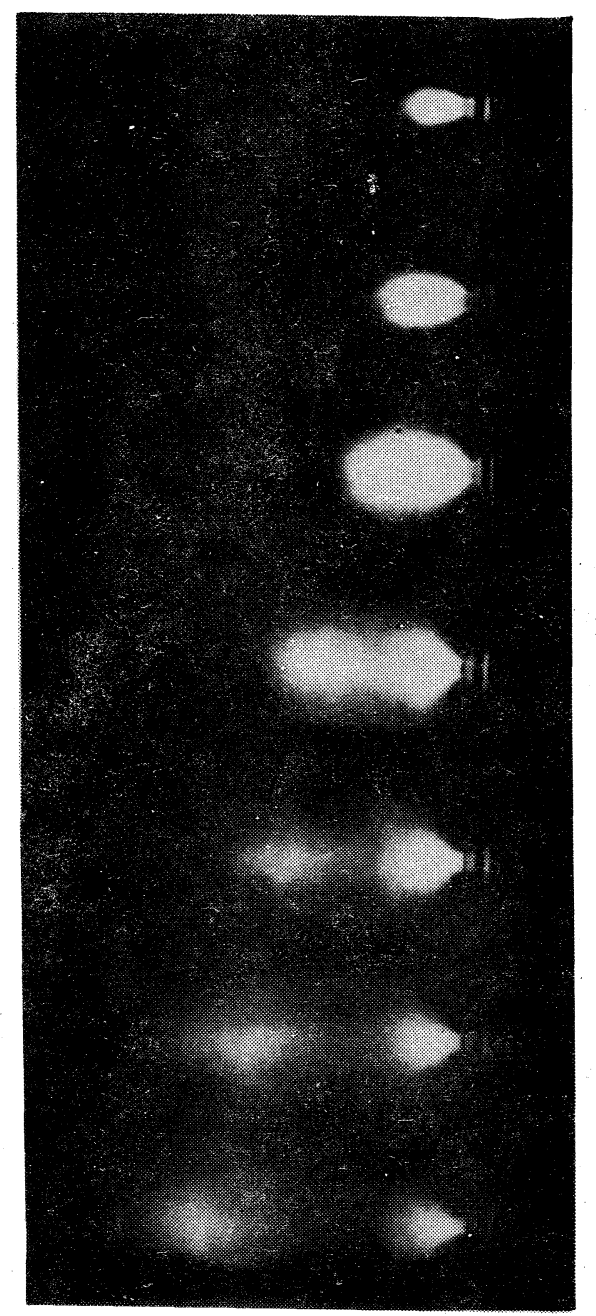

Fig.11 上よりパフ舄作後 $250 \mu \mathrm{sec} 300 \mu \mathrm{dec}$

$350 \mu \mathrm{soc} \quad 400 \mu \mathrm{sec} \quad 450 \mu \mathrm{sec}$

$500 \mu$ we $550 \mu \mathrm{sec}$

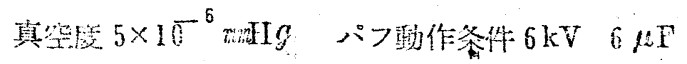

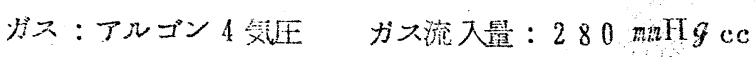




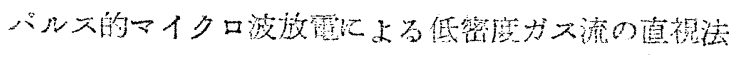

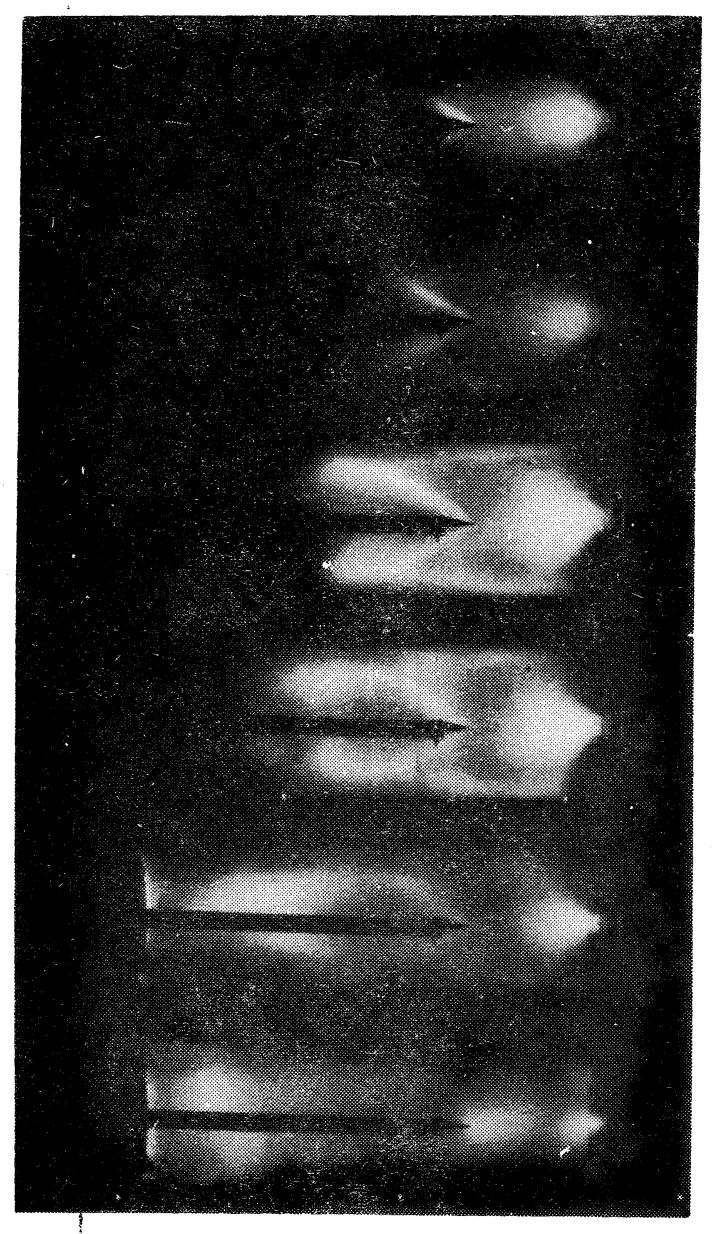

Fig.12 上よりパフ魏作㖟 $350 \mu \mathrm{sec} \quad 400 \mu \mathrm{sec}$

$450 \mu \mathrm{sc} \quad 500 \mu \mathrm{sec} \quad 600 \mu \mathrm{sec}$

$1000 \mu x$

- H又: 空氮1 领E 


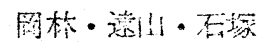

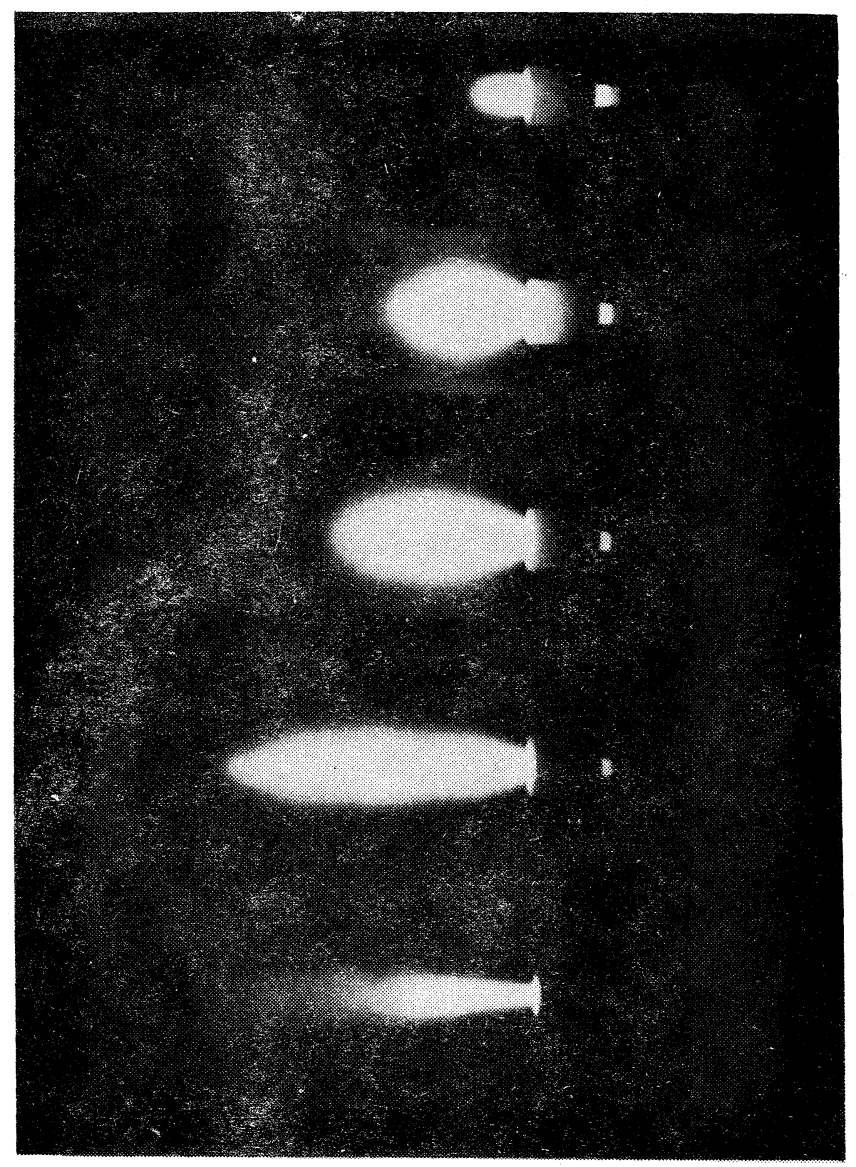

Fig.13 上よりパフ動作後 $350 \mu \mathrm{sec} 400 \mu \mathrm{sec}$ $500 \mu \mathrm{sec} \quad 600 \mu \mathrm{sec} .700 \mu \mathrm{sec}$ グス：アルゴン 4 気压

真空度 $1.4 \times 10^{-5} m \mathrm{Hg}$ 


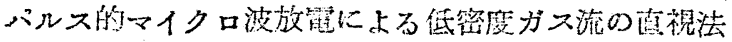

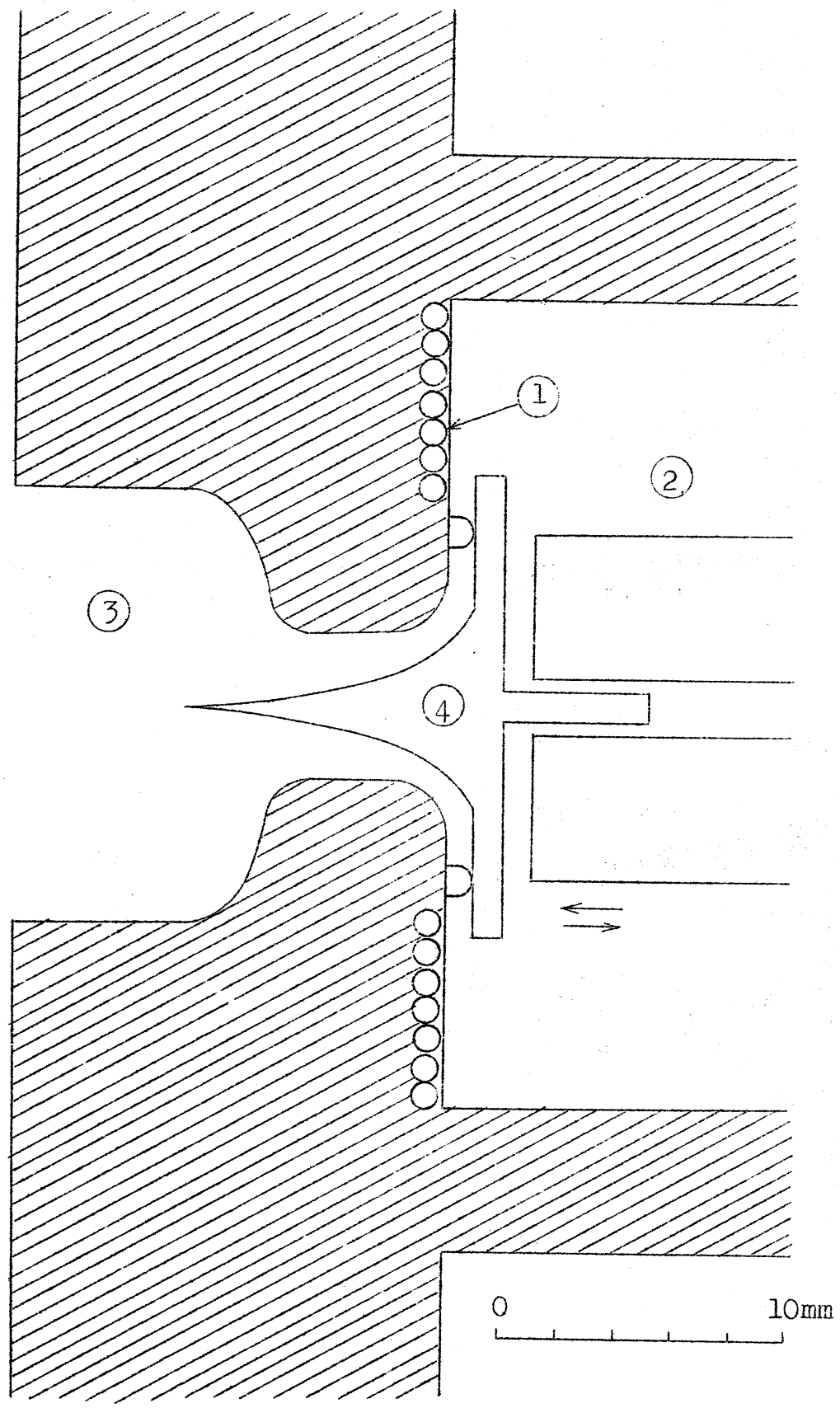

Fig.14 改良された高速度弁 (1) コイル (2) ガス溜

(3) 噴出口 (4) アルミ・デイスク 


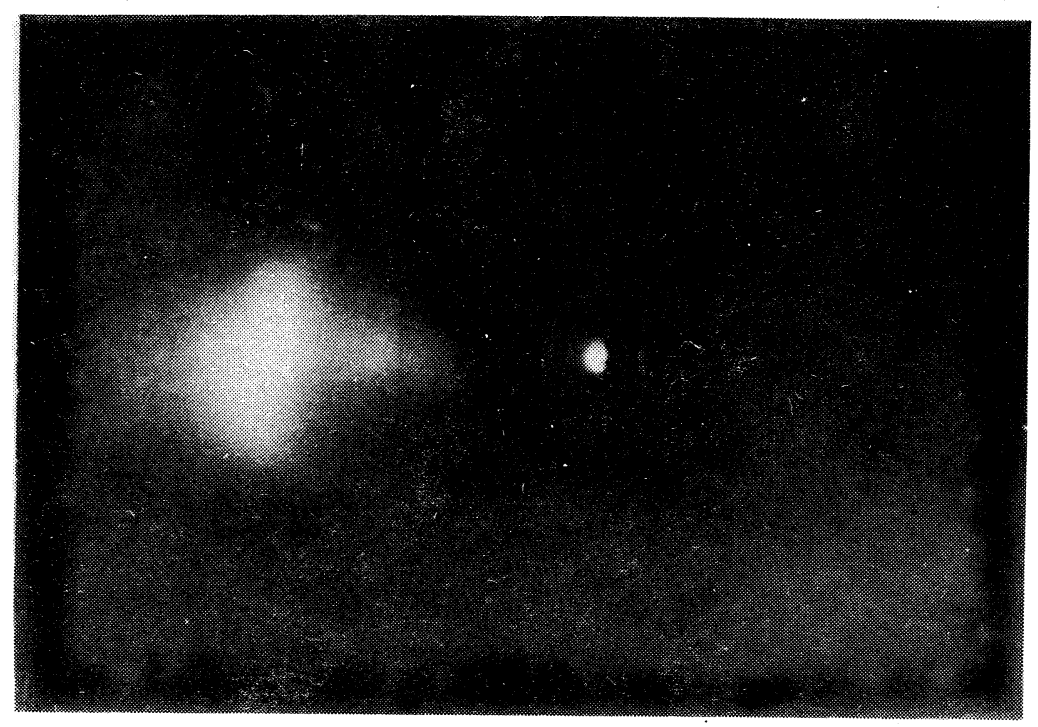

Fig・15 Fig.14のパフに上るガス喷出の螊子。 パフ動作後 $500 \mu$ aec 後 (アルゴン 4 気压)

\section{$\S 6$ むすびと熘碚}

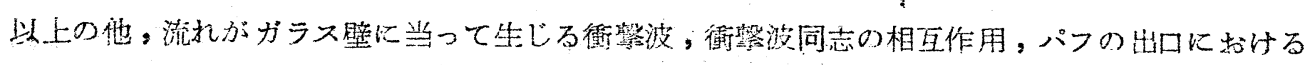

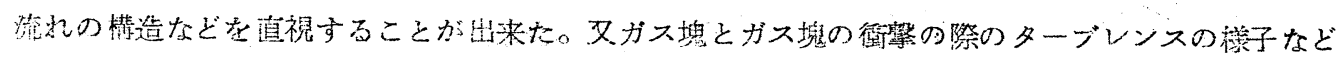
当調人得百と思われる。

我々の萑視法は，流れの(少くとも宗性的な)測定に有効であると結諭出来る。我々は大方の批 判を受けてこの方法の改示を期したい。

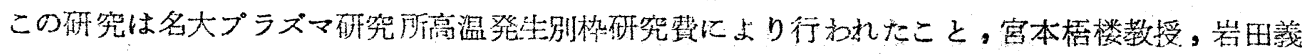

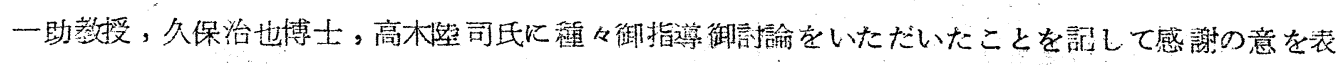
士5。 


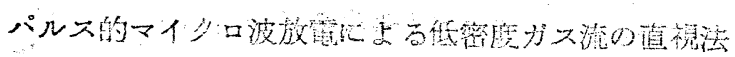

参考文献

1) 国枝俊介：核融合研究 11 (1963) 263

2) 平野恵一： $12(1964) 98$

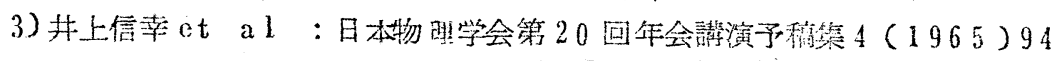

4) 国中正悛：輆融合研究 12 (1964) 428

5) J. Marshall : Plasma Accelerator (Kash editor, Stanford Univ. Press. 1960) 1.60

6) Hung -Ta-Ho et al : Rarefied Gas Dynamics Fourth Symposium

(L. Talbot editor, Academic Press 1961) 539

7) 舅本健郎: 核融合研究 12 (1964) 429

8)Eva M. Winkler : Physical Measurements in Gas dynamics and Conbusion (R. W. Landenburg et al editors. Princeton Univ. Press 1954) 79

9) A.D Hacionald et al : Phys. Rev. 130 (1963) 1841

10)W.P. Allis et al : Phys. Rev. $\quad \underline{87}$ (1952) 419

1i)R.S. Lowdon and F.C. Hoh : R.S.I 33 (1962) 1236

12)J. B. Anderson et al : Fhys. Fluids 8 (1965) 780 